\title{
REVIEW
}

\section{Sustainable productive intensification for family farming in developing tropical countries}

\author{
Intensificação produtiva sustentável na agricultura familiar em países \\ tropicais em desenvolvimento
}

\author{
'Instituto Nacional de Colonização e Reforma Agrária/INCRA, Lavras, MG, Brasil \\ ${ }^{2}$ Universidade Federal de Lavras/UFLA, Departamento de Ciência do Solo/DCS, Lavras, MG, Brasil \\ ${ }^{*}$ Corresponding author: niltcuri@ufla.br \\ Received in May 20, 2019 and approved in July 11, 2019
}

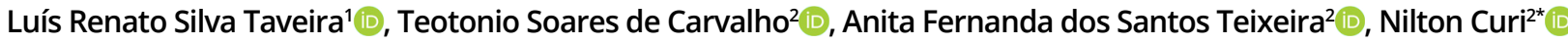

\begin{abstract}
In the past, agriculture was directed to satisfying human needs. Nowadays, it is directed to meeting the markets, forcing the peasantries to adapt to this condition. As a result, family farmers are multifaceted, incorporating both subsistence and market-oriented production. Traditional farming systems have been challenged since there is a pressure for the intensification of these systems. Then, it is important that scientific research about them goes on to recognize that many family farmers use limited resource bases. However, innovation and intensification are permanent needs of agriculture, although they must be adjusted to different contexts, respecting the cultural legacy of family farmers as a prerequisite for achieving the development.
\end{abstract}

Index terms: Farming system; sustainability; family farmer; capitalism; food production.

\begin{abstract}
RESUMO
No passado, a agricultura era direcionada para satisfazer as necessidades humanas. Hoje em dia, é direcionada para atender os mercados, forçando o campesinato a se adaptar a essa condição. Como resultado, os agricultores familiares se tornaram multifacetados, incorporando tanto a produção de subsistência quanto aquela orientada para o mercado. Os sistemas agrícolas tradicionais foram desafiados, uma vez que existe uma pressão para a intensificação desses sistemas. Então, é importante que a pesquisa científica sobre eles continue para reconhecer que muitos agricultores familiares usam bases de recursos limitadas. Contudo, inovação e intensificação são necessidades permanentes da agricultura, embora elas devam ser ajustadas a diferentes contextos, respeitando o legado cultural dos agricultores familiares como pré-requisito para alcançar o desenvolvimento.
\end{abstract}

Termos para indexação: Sistemas agrícolas; sustentabilidade; agricultor familiar; capitalismo; produção de alimentos.

Not every farmer aims at capital accumulation, although this is the dominant mindset nowadays. Peasant farmers hold cultural values among which there is no motivation for profit in agricultural production, and the farming systems they use reflect that. The expansion of capitalism, however, is changing their way of life. Entrepreneurship can offer opportunity for business development or a route to economic survival for the farmer fit (Fitz-Koch et al., 2018). The family farmers are the most visible result of these changes in the way of life. Part of them incorporates, to varying degrees, the dominant productive logic, although they may maintain part of the peasant cultural values. They are multifaceted, adapted to different contexts. Although threatened to disappear as a social category, they are still culturally and economically important, especially in tropical developing countries.

Two demands are imposed on humanity in the $21^{\text {st }}$ century: respect for diversity and search for sustainability in any human activity. Therefore, it is necessary to ensure family farmers conditions to perpetuate their way of life, while respecting those who have consciously opted for incorporation into the capitalist economy. For that, public policies, such as the agrarian reform carried out by the National Institute of Colonization and Agrarian Reform (INCRA) in Brazil, economic structures and scientific research need to be adapted to the needs of this part of society. In this context, this study aims to characterize 
the current Brazilian family farming, as well as its cropping system changes, the causes of its persistence, technical demands, and to identify sustainable options for intensifying agricultural production in family farms.

\section{Family farming}

It is necessary to distinguish family farmer from peasant farmer. Although they keep correspondences, they are not coincident categories (Rigg; Salamanca; Thompson, 2016). Peasant farming is characterized by non-capitalist productive logic, based on great social, cultural and technical diversity. Its main objective is to provide the social reproduction and subsistence of the family and the community (García-Flores et al., 2016). It presents relative autonomy and small market integration. Peasant farming is a tradition in agriculture of Europe and Asia, also common among native and traditional populations of America, Africa and Oceania. Moreover, it is multifunctional, going beyond production limits and incorporating other aspects (Rivas; Quintero, 2014). Among South American indigenous people, for instance, cultivation aims at food subsistence and is also both a social and a religious practice (Felipim; Queda, 2005). Many communities descending from indigenous traditions perpetuate this legacy (Sabourin, 2009; Junqueira et al., 2016a). The capitalist development, however, induced the peasant farmers to adapt to the new reality.

Family farmers share many peasant traditions, while adapting to the new times (Table 1), according to Rigg, Salamanca, and Thompson (2016). Their multifaceted nature includes subsistence production, essentially peasant, and capitalist production (Bazin, 1998). Their main features are the predominance of family labor and particular forms of succession regarding land tenure. The close community relationship, the multiple strategies of survival, the management of relatively autonomous and limited resources bases, the decisions taken jointly by the family and the technical choices dictated by the cultural tradition are also important (Sabourin, 2009; Urcola, 2013; García-Flores et al., 2016). Characteristics such as sustainability and the small size of holdings are, however, circumstantial. They depend on the farming system and on the access to technical and financial resources (Vliet et al., 2015).

More farmers are continuously incorporating the new productive logic and new technologies. There are researchers who understand that the full insertion of family farmers into the capitalist economy is more effective in combating poverty than protecting traditional ways of life (Soper, 2016). If these changes result only from farmers' autonomous decisions, there would be no opposition to this thesis. In most cases, however, they are motivated by iniquities in public policies and markets. Many countries restrict traditional farming systems to favor those integrated to the market ( $\mathrm{Li}$ et al., 2014; Zanella; Milhorance, 2016). Furthermore, despite these restrictions, there are still approximately 350 million indigenous worldwide, peasant and family production units, on which depends the survival of 1.5 billion people, about $20 \%$ the world's population. These farmers occupy $20 \%$ cultivated land and produce approximately $50 \%$ food for domestic consumption (Altieri; Nicholls, 2017).

Vignola et al. (2015) consider that family farmers are sensitive to globalization, population growth and climate change. This context threatens their food security and cultural legacy, although the great technical diversity of their farming systems favors the coexistence with uncertain scenarios (Altieri; Funes-Monzote; Petersen, 2012; Altieri; Nicholls, 2017). Scientific research and public policies for family farming are becoming widespread. However, it is still necessary to better understand their characteristics and to construct viable technical and economic alternatives for these farmers, favoring development, overcoming poverty and protecting their technical and cultural legacy.

Table 1: Characterization of the peasant farmer and family farmer.

\begin{tabular}{ccc}
\hline Category & Main Feature & Definition \\
\hline Peasant farmer & Motivation (subsistence) & $\begin{array}{c}\text { Subsistence production, limited resource base } \\
\text { and small market integration. It is considered a } \\
\text { subordinate class. }\end{array}$ \\
Family farmer & $\begin{array}{r}\text { Origin of labor force and } \\
\text { rights of succession }\end{array}$ & $\begin{array}{r}\text { It has similarities with the peasant farmer but can } \\
\text { incorporate motivation for profit. Labor is essentially } \\
\text { familiar. The productive unit tends to be a social unit } \\
\text { (family). Small units predominate, but mechanization } \\
\text { can soften this limitation. }\end{array}$
\end{tabular}

Source: Adapted from Rigg, Salamanca, and Thompson (2016). 


\section{Traditional farming systems of family farming}

The following typology of farming systems, adapted from Kovacic and Viteri Salazar (2017), is considered hereafter: traditional, intensive and agroecological systems. A farming system is a way of organizing the resources needed for production, according to local availability and to social needs (Carmona et al., 2010). If the natural limits of ecosystems are respected, it will be sustainable, preserving or even improving the farmer's resource base (Pretty; Bharucha, 2014). Family farming often develops a wide variety of farming systems.

Subsistence production is common in developing tropical countries due to limited resource bases and precarious living conditions. But a portion of family farmers has already entered into the market (Urcola, 2013). In these countries there is a cultural environment that devalues old agricultural practices. In developed temperate countries, however, the environmental crisis is highlighting the main contribution of family farming to humanity: the development of farming systems that, while preserving technical and cultural legacies, are capable of providing both the farmer's livelihood and producing for the market (Belletti, 2015).

Any farming system imposes a degree of simplification and instability on ecosystems (Pretty; Bharucha, 2014). There are studies that compare natural and cultivated ecosystems, proving significant changes after anthropic interference (Lima et al., 2011; Raczkowski et al., 2012; Béliveau et al., 2015). However, there are still very few studies comparing the global impact of traditional and intensive systems (Mukul; Herbohn, 2016), especially in the long run (Prokop; Poręba, 2012). This is essential for society to choose its paths in search of development.

Traditional systems express the cultural legacy of many ethnic minorities (Li et al., 2014). They are associated with particular forms of family relationship and social organization. The cultivation of land has, for these minorities, a character that goes beyond simple food subsistence. It is common to organize production in agreement with the community, harmonizing individual and collective needs (Altieri; Toledo, 2011). The use of external inputs is small and family labor predominates. Each aspect of these systems is adjusted according to the characteristics of the family (Kovacic; Viteri Salazar, 2017) and of its resource base (Vosti; Witcover, 1996; Junqueira et al., 2016b).

Farmers hold practical knowledge whose scientific value has been gradually recognized (Nyssen et al., 2008). Lines of research seeking to establish dialogues between both forms of knowledge have becoming increasingly common. Among the teachings of traditional systems can be cited submission to climatic seasonality, ecological succession and biogeochemical cycles. Its sustainability depends on respecting ecosystem limits and good management practices.

Among traditional systems, shifting cultivation systems are technically the most rustic ones. It is estimated that, in the Brazilian Amazon alone, between 600,000 and 1 million families use them for their subsistence (Tremblay et al., 2015). The systems of coivara (Brazil), milpa (Mexico) and jhum (India), among others, are variations of the same technique (Sánchez, 1982; Kleinman; Pimentel; Bryantc, 1995; Thomaz; Antoneli; Döerr, 2014) (Figure 1), in which the agricultural practices disrupt nutrient cycling, accelerate the mineralization of organic matter, increase greenhouse gas emissions, reduce biological diversity, and increase erosion processes.

Fire changes soil chemical attributes: it increases exchangeable cations and available phosphorus, increases $\mathrm{pH}$, slightly increases total carbon, decreases nitrogen, potassium, iron, aluminum and manganese near the surface, but increases them in subsurface (Kleinman; Pimentel; Bryantc, 1995; Thomaz; Antoneli; Döerr, 2014; Béliveau et al., 2015). Changes in soil physical attributes are due to changes in microbial composition and activity, organic matter transformations, and clay fraction behavior, which modify soil resistance to erosion, depending on other soil properties and vegetation characteristics (Herrick et al., 2018). The severity of these disturbances depends, however, on the environmental conditions at the time of burning, the fire intensity, the size of the area, the characteristics of the residues and the soil type (GonzálezPérez et al., 2004; Mataix-Solera et al., 2011; Inbar et al., 2014; Jiménez-Pinilla et al., 2016).

Exposure of soil during cultivation accelerates erosion and increases redistribution of soil surface material along slopes (Vanacker et al., 2019). There are studies, however, proving the exponential reduction of losses during fallow, as plant cover is recomposed (Thomaz, 2013); and evidence that, given the reduced size of cultivated areas in these systems, soil eroded at one site is not transported over large distances (Lestrelin et al., 2012). The soil cover through agricultural practices reduces this problem (Seitz et al., 2019).

Naturally fertile soils better support the management of shifting cultivation systems (Junqueira et al., 2016a). The higher the natural soil fertility, the longer the cultivation period can be. But since no fertilizer is applied, soil reserves are rapidly consumed (Thomaz; Antoneli; Döerr, 2014; Béliveau et al., 2015; Mukul; Herbohn, 2016). The reduction of this stock depends on the cultivation conditions (Sánchez, 1982). 

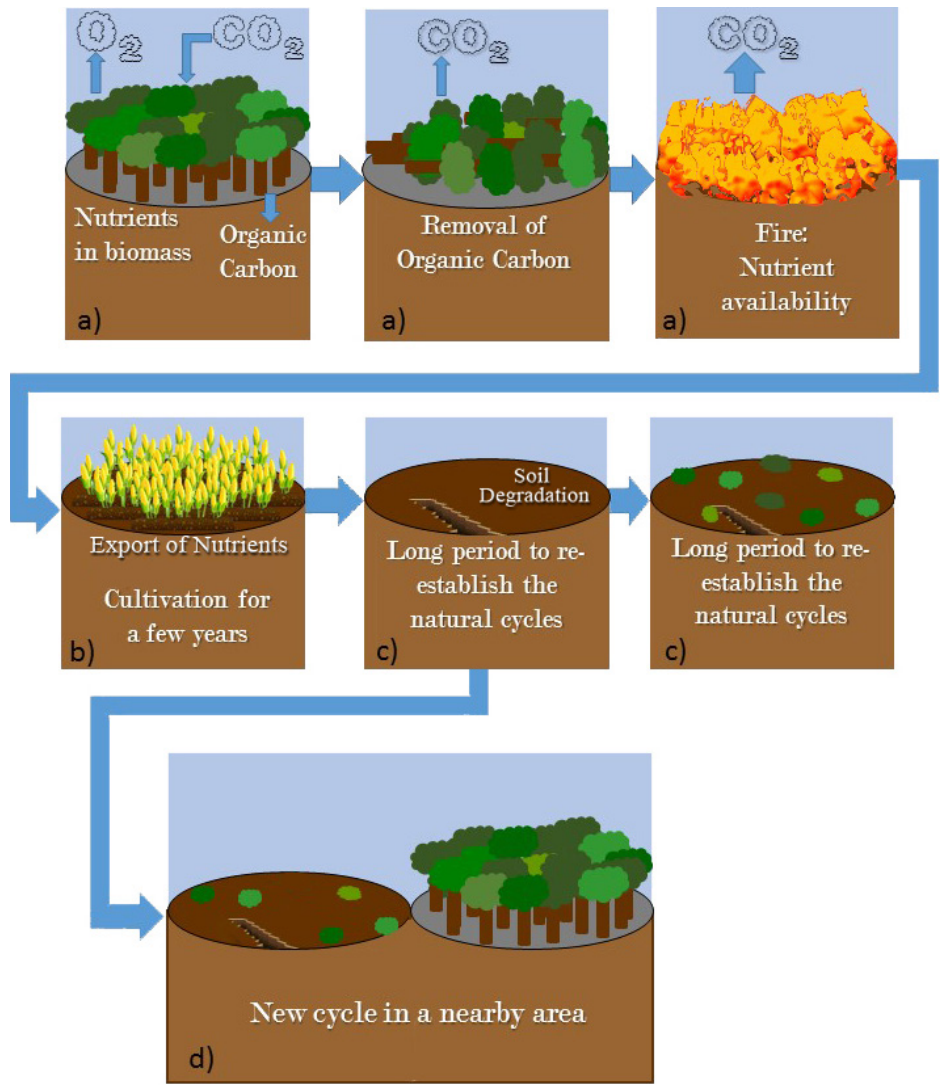

Figure 1: Shifting cultivation systems techniques. a) opening of clearings in the forest and burning of the plant residues (slash and burn) to eliminate competition for light, water and providing nutrients stored in the biomass; b) cultivation of small subsistence swiddens for a few years, providing biological diversity and conservation of soil and water; c) fallow for a long period to re-establish the natural cycles and characteristics of the disturbed ecosystem; d) new cycle (shifting cultivation) in a nearby area.

Source: Constructed from Kleinman; Pimentel; Bryantc, 1995; Thomaz; Antoneli; Döerr, 2014; Béliveau et al., 2015; Herrick et al., 2018.

Ecological succession is also disturbed by the removal of vegetation, which can affect the success of passive restoration (Prach et al., 2019). Although studies on deforestation are common, when the influence of shifting cultivation systems is analyzed, generalizations make it difficult to understand the problem. However, there are studies showing that, in regions where these systems are still common, the decline in native vegetation cover is a result of improved infrastructure, which favors all types of enterprises, including intensive cultivation (Hansen; Mertz, 2006; Carmona et al., 2010). The analyses do not specify the impact of each farming system on a global scale. It is necessary to consider, however, that shifting cultivation systems involve small areas with many species and varieties, including native ones (Mukul; Herbohn, 2016).
The rebalancing of these disturbances depends on the management of the relative size of the cultivation and fallow periods. Aspects such as soil natural fertility, size of cultivated area, richness of remaining forests and intensity of disturbance condition this management (Junqueira et al., 2016a; Mukul; Herbohn, 2016). The fallow period restricts the food production, but it is determinant for the recovery of soil characteristics and vegetation cover at maximum periods of a few decades (McNicol; Ryan; Williams, 2015; Morales-Barquero et al., 2015). Thus, fallow land should be considered as a management practice whose size must be adjusted by the farmer to reestablish natural cycles and to perpetuate the supply of environmental services (Kleinman; Pimentel; Bryantc, 1995; Wood; Rhemtulla; Coomes, 2016).

Shifting cultivation systems do not survive along with excessive population growth and urbanization, which 
threaten the ways of life of ethnic minorities and traditional populations (Bermeo; Couturier; Galeana Pizaña, 2014). The social exclusion of the shifting cultivators and the uncontrolled population growth result in overexploitation of their resource base and the degradation of forests and soils (Vosti; Witcover, 1996; Wagner; Yap; Yap, 2015), a process that gradually reduces the possibility of restoration of natural cycles (Prokop; Poręba, 2012).

Mukul and Herbohn (2016) and Vliet et al. (2012) show how scarce, on a global scale, research on these systems is. Even rarer are the comparative studies between their impacts and those of intensive systems, considering the whole cycle. Still, shifting cultivation systems are the preferred target of policies to combat deforestation (Kleinman; Pimentel; Bryantc, 1995). They are victims of gaps in knowledge about them:

a) The small scale of production in these systems makes it difficult to map swiddens by remote sensing or in loco (Hett et al., 2012);

b) It is necessary to clearly identify which farmers and which farming systems are responsible for deforestation and forest and soil degradation (Müller et al., 2013);

c) Most of the knowledge about the fire impacts on forest ecosystems refers to the effects of large fires on temperate forests (González-Pérez et al., 2004; Mataix-Solera et al., 2011); in shifting cultivation systems, the burnings are shorter and temperature peaks are smaller, just enough to increase nutrient availability in the soil (Thomaz, 2017); d) Short fallows may compromise the sustainability of the system (Thomaz, 2013); the limits that each ecosystem imposes on the balance between the cultivation and fallow periods are, however, little known;

e) Shifting cultivation systems handle large cultivated biological diversity (Junqueira et al., 2016a), including endangered species, and this needs to be recognized; and native biological diversity is only impaired if fallow period is smaller than the necessary, if the deforested area is large or if the same area is repeatedly cultivated (Mukul; Herbohn, 2016);

f) Carbon emissions into the atmosphere depend on the type of burning; it is necessary to analyze the entire cycle, since after the cultivation period of the ecological succession resumes carbon sequestration (Tinker; Ingram; Struwe, 1996); it is also important to deepen the knowledge about the biochemical transformations of recalcitrant carbon forms in soils subjected to such fires (GonzálezPérez et al., 2004).

Despite the controversy over these farming systems, it is observed that, far from disappearing, they persist in several regions (Hansen; Mertz, 2006; Mertz et al., 2012;
Vliet et al., 2012) of Africa, Latin America and Asia. There are ethnic minorities that perpetuate their cultural legacies. And there are others that distance themselves from their origins. The persistence of these farmers occurs, in this case, on different cultural bases: pressured by social exclusion and uncontrolled population growth, they tend to intensify production and cause greater impacts (Bautista; Smit, 2012; Rahman; Rahman; Sunderland, 2012; Emperaire; Eloy, 2015; Wagner; Yap; Yap, 2015). However, these systems are sustainable as long as environmental limits are observed (Tinker; Ingram; Struwe, 1996).

The finite availability of arable lands, the population growth and the search for survival have always been the motivations for technical innovation in agriculture. Farming systems became increasingly perennial, and the living conditions of the communities improved for a long time without this meant changes in the productive logic (Pretty; Bharucha, 2014). The most significant innovations include drainage, rainwater harvesting, animal-drawn implements, addition of organic wastes to soil and natural phytosanitary treatments (Miltner; Coomes, 2015; GarcíaFlores et al., 2016; Altieri; Nicholls, 2017). Agroforestry systems, mixed crops integrated by native tree species, food crops and forage crops, also stand out. They allow the intensification of shifting cultivation systems without exceeding the ecosystem limits (Tremblay et al., 2015). There are numerous adaptations: agroforestry backyards (Moreno-Calles et al., 2016), shaded swiddens (Vallejo et al., 2014), commercial orchards in the midst of regenerating forests (Wood; Rhemtulla; Coomes, 2016), among others.

Therefore, agroforestry systems are considered as an appropriate alternative for the intensification of shifting cultivation systems (Rahman; Rahman; Sunderland, 2012; Tremblay et al., 2015). Their widespread dissemination may, however, interferes with the perpetuity of sensitive environmental services such as pollination and natural pest control (Wood; Rhemtulla; Coomes, 2016). Thus, although it is an ancestral technique, it is necessary to deepen the understanding of its dynamics through new studies. It is also needed to consider that the standardization of eating habits discourages the adoption of this alternative. Many communities tend to abandon native foods, opting for more expensive industrialized products, reducing their food security (Moreno-Calles et al., 2016).

Innovation has always been a feature of agriculture. The difference between traditional and intensive farming systems, in this respect, is the impact of new technologies (Pretty; Bharucha, 2014). There are situations in which innovation and intensification of farming systems are accompanied by a change in the productive logic. This 
should not be taken as negative when resulting from conscious decisions by farmers. However, in developing tropical countries the motivations for such changes are often the precarious living conditions in which family farmers survive. Intensification must be an alternative, not an imposition. Its effectiveness depends on respect for the cultural legacy of rural communities.

\section{Conventional intensification of farming systems}

Family farmers who have joined capitalist production and new technologies through conscious decisions enjoy all the benefits and face all the inherent challenges (Urcola, 2013). However, here it is only necessary to analyze the partial incorporation of this new paradigm into the traditional systems, the resulting problems and the possible alternatives.

Intensive systems emerged in response to the expansion of capitalism and the growing demand for raw materials and food (Brown; Gil, 2003). They allowed the expansion of production and agricultural productivity to unprecedented levels. Since the $19^{\text {th }}$ century, the spread of capitalist production, and innovations in chemistry, genetics, irrigation, and mechanics have changed agriculture.

These changes occurred initially in developed temperate countries. Once a provider of human needs, agriculture became a supplier of inputs to markets, on an industrial scale (Bautista; Smit, 2012; Kovacic; Viteri Salazar, 2017). But the new technologies have been developed in specific social and environmental contexts, outside of which they may cause negative impacts (Gaona; León; Valverde, 2012). They have become evident in the last decades with the repetition of crises arising from the application of these technologies out of context.

In more recent years, growing global awareness of these imbalances has led agriculture to innovations to minimize them. Minimum tillage and no-tillage systems, micro-sprinkler and drip irrigation, biological nitrogen fixation, and other advances are relevant. In this aspect, there are possibilities not yet or little explored in order to make the intensive systems more sustainable (Stavi; Bel; Zaady, 2016). Table 2, according Martínez-Castillo (2008), shows a brief description of traditional and intensive systems.

Expansion of production, reduction of food insecurity on a global scale, and improvement in farmers' living conditions are the main arguments in defense of intensive systems (Zanella; Milhorance, 2016). However, still today, approximately 850 million people face malnutrition, $70 \%$ of them in rural areas of tropical developing countries (García-Flores et al., 2016). The causes of this problem go beyond the frontiers of agricultural production. Inadequacies in markets regulation, imbalances in income distribution, and political and humanitarian crises are directly responsible for the persistence of hunger in the $21^{\text {st }}$ century (Pretty; Bharucha, 2014). The intensification of farming systems, therefore, is not capable of solving it alone.

The new paradigm presupposes farmers to be able, financially and culturally, to adopt the intensive systems. This is not the reality of many developing tropical countries where limited access to land, to formal education, and to technical and financing resources constrain the conventional intensification of farming systems. This results in only partial application of new technologies, replacing low-cost ancestral practices with others, usually more expensive, without the certainty of proper use. Those who are unable to fully incorporate the new paradigm tend to worsen their living conditions: they do not always achieve greater productivities, but they compromise their income through the acquisition of inputs. Dependence on financing and acquisition of inputs reduces the autonomy of productive units. When it occurs, the partial productive intensification results from stimuli related to rural credit or subsidies, or from restrictions on forest legislation, land tenure, migration, investment

Table 2: Traditional and intensive farming systems features.

\begin{tabular}{ccc}
\hline Feature & Traditional & Intensive \\
\hline Energy & Mainly renewable & Fossil fuels \\
Goal & Focus on collective needs, little dependent on & inputs \\
Labor force & Family or communal & $\begin{array}{c}\text { Focus on private interests, heavily } \\
\text { dependent on inputs }\end{array}$ \\
Diversity & High biological diversity & Employed \\
Knowledge & Local, traditional & Low biological diversity \\
\hline
\end{tabular}

Source: Adapted from Martínez-Castillo (2008). 
capacity or market requirements (Bautista; Smit, 2012; Gaona; León; Valverde, 2012; Lestrelin et al., 2012; Rahman; Rahman; Sunderland, 2012; Pérez-García; del Castillo, 2016; Kovacic; Viteri Salazar, 2017).

There are researchers who defend mixing traditional and modern agricultural technologies as an alternative to increase production and sustainability (Stavi; Bel; Zaady, 2016). However, options like this need to be analyzed by looking at the nature of the constraints that many family farmers face to intensify their farming systems. The transition from traditional to intensive systems is a continuum in which each farmer positions himself, and agroecological systems are an alternative that is accessible to all. They are particularly adapted to those who wish to intensify production but do not meet all conditions for adoption of intensive systems (Altieri; Toledo, 2011). In the agroecological transition, the more preserved the agroecosystems the easier the change will be.

\section{Agroecological intensification of farming systems}

Since the 1970s, the environmental movement has brought new issues to the public domain. Initially it was fighting economic growth. Later this thesis changed: development should be guided by environmental issues. Only in the last decades, however, the social and cultural demands have been emphasized (Martínez-Castillo, 2009).

Agroecology is a science that applies ecological principles to the study and development of farming systems. It is the conceptual basis of practices that seek to overcome the industrial and capitalist logic of agricultural production. It is adapted both to productive intensification on marginal lands and to family farming (Brown; Gil, 2003). It presupposes the recycling of energy and nutrients, the stimulation of soil microbial activity, the diversification and integration of crops and livestock raising, and the use of native genetic resources. By diverse mechanisms, it favors the stability of production and improves the living conditions of farmers (Altieri; Toledo, 2011).

Agroecological systems are adapted to farmers with low investment capacity and small resource bases (Moreno-Calles et al., 2016). They favor the protection to cultural legacies, innovation in horizontal networks, family production, productive autonomy, biological diversity of agroecosystems, associativism, fair trade, local market and close relationships between producers and consumers, which are valued due to ongoing social changes (Altieri; Toledo, 2011; Darolt et al., 2016). Biodynamic agriculture, organic agriculture and permaculture are some of the agroecological groups (Brown; Gil, 2003). All of them are based on techniques little aggressive to the human beings and the environment. They incorporate farmers' knowledge, to which they aggregate others, favoring their resistance against threats to their way of life (Altieri; FunesMonzote; Petersen, 2012). The incorporation of social and cultural demands into economic and environmental issues is the differential of agroecological systems (Martínez-Castillo, 2009).

There are organic-based farming systems that do not break farmer's dependence on external inputs and distant markets, and therefore should not be confused with agroecological systems (Altieri; Toledo, 2011). The productivity of each crop, taken individually, is usually higher in intensive systems. However, when it is analyzed from the sum of the harvests in polyculture systems, the biological diversity and the energy balance, agroecological systems tend to present advantages. These systems are therefore a good alternative to overcome poverty, achieve food security and the sustainability of agriculture, even if the agroecological transition causes a reduction in crop productivity until a new equilibrium condition is reached. Although they have advantages, they still depend on cultural changes in capitalist society to spread (Martínez-Castillo, 2009; Altieri; FunesMonzote; Petersen, 2012), and this takes time.

Use of biological agents, such as nitrogenfixing bacteria, plant growth promoting rhizobacteria, mycorrhizal fungi and organisms for the biological control of pests and diseases, is an alternative to increase yields in several crops in agroecological systems (O'Callaghan, 2016; Assainar et al., 2018; Togni et al., 2019). In addition to the use of commercial products, onfarm multiplication of inoculants has also been evaluated (Englander; Douds; Mallory, 2016; Hart et al., 2018) and already being used by farmers, along with simple techniques of multiplication and asepsis, to reduce the cost with inoculants.

Green manure is a strategy being used by family farmers to diversify the production system, add organic matter, cycle and add nutrients and cover, and protect the soil. Legume species such as jack bean (Canavalia ensiformis), black bean (Phaseolus vulgaris), lab-lab bean (Dolichos lablab) and crotalaria-juncea (Crotalaria juncea) are preferred for consortium and green manuring for symbiosis with nitrogen-fixing bacteria, adding this nutrient to the system (Souza et al., 2018). This practice has made production more sustainable by increasing productivity and reducing environmental impacts (Filipe et al., 2016; Xie et al., 2016; Meena et al., 2018). 


\section{Persistence of traditional farming systems}

There are several reasons to protect traditional systems from disappearing: proper management of cultivated biological diversity (Junqueira et al., 2016a; Fernandes; Silva; Falcão, 2018); maintenance of natural biological diversity at appropriate levels (Mukul; Herbohn, 2016); maintenance of adequate soil carbon stocks (Tinker; Ingram; Struwe, 1996); energy efficiency dictated by the small use of inputs; relatively small soil losses; food security for hundreds of millions of human beings; and protection to the cultural legacy of countless ethnic minorities and traditional populations (Altieri; FunesMonzote; Petersen, 2012).

Many farmers use traditional systems to preserve their way of life (Bermeo; Couturier; Galeana Pizaña, 2014; Emperaire; Eloy, 2015): in many developing tropical countries the low degree of formal education does not give them opportunities for integration in the capitalist economy in dignified conditions. Even in countries with rapid economic growth, many farmers are attracted by job opportunities outside their farms, but maintain their own swiddens. It is a way of improving living conditions and preserving cultural traditions (Hansen; Mertz, 2006).

Protecting the cultural legacy associated with traditional systems and their agro-ecological heirs favors access to high quality food, with environmentally and socially adjusted technical solutions (Altieri; Funes-Monzote; Petersen, 2012). Moreover, family farming and its farming systems are the key to the current environmental crisis (Belletti, 2015): they produce relatively few negative impacts and how they use few inputs, protect farmers against price fluctuations in the market (Mertz et al., 2012; Li et al., 2014).

The incorporation of many family farmers - also indigenous communities - to the market has justified the defense of global market as the best way to improve their social and economic condition (Soper, 2016). However, local markets and proximity between producers and consumers are trends that are part of a major global movement to reintegrate poor farmers into society. Local supply networks tend to grow among global ones, complementing them, and it is a misconception to associate them only with highincome consumers. It is necessary, however, to recognize that there are still obstacles to their dissemination to guide public policies and consumer education (Darolt et al., 2016).

In recent decades, developing tropical countries have been victims of the intense countryside population migration to cities. This process depopulated rural areas, whose revaluation involves associating family farmers with national development projects. This demands articulated public policies of access to land, health and education, infrastructure improvement and fair trade, among others. They need to be flexible to adapt to regional realities.

\section{Adapted technological alternatives for developing tropical countries}

Traditional farmers, including shifting cultivators, have managerial capacity, but use limited resource bases and are, therefore, sensitive to any restrictions on their activity (Junqueira et al., 2016b). The main obstacles to communication between farmers and scientists are due to differences in understanding the world. The experience of farmers is an important source of knowledge, translated into adapted farming systems (Nyssen et al., 2008). Therefore, it is necessary to improve the dialogues with them, rediscovering traditional technologies, collaboratively building appropriate solutions and disseminating them widely (Hernández-Hernández et al., 2011; Yengoh; Brogaard, 2014; Altieri; Nicholls, 2017). This adaptation favors sustainability, cohesion of rural communities and protection of their cultural legacy (Vliet et al., 2015), in line with the concept of sustainable intensification (Table 3), as outlined by Pretty and Bharucha (2014).

Table 3: Conventional and sustainable forms of agricultural intensification.

\begin{tabular}{|c|c|c|}
\hline & Conventional & Sustainable \\
\hline Goal & Increase production & $\begin{array}{l}\text { Increase production, natural and social capital, } \\
\text { build knowledge }\end{array}$ \\
\hline Knowledge & $\begin{array}{l}\text { Created by experts, disseminated in } \\
\text { conventional rural extension networks }\end{array}$ & $\begin{array}{l}\text { Created by experts and farmers, disseminated } \\
\text { in collaborative rural extension networks }\end{array}$ \\
\hline $\begin{array}{l}\text { Environmental } \\
\text { services }\end{array}$ & $\begin{array}{l}\text { Derived from cultivated landscapes. } \\
\text { Replacement of regulation services with } \\
\text { inputs. Interactions with the natural } \\
\text { landscape are externalities }\end{array}$ & $\begin{array}{c}\text { Appreciation of multiplicity of environmental } \\
\text { services of cultivated and natural landscapes, } \\
\text { and the correlation between them }\end{array}$ \\
\hline
\end{tabular}

Source: Adapted from Pretty and Bharucha (2014). 
There is a growing demand for better social and environmental standards in agriculture. This includes traditional systems, often associated with unsustainable patterns of exploitation dictated by poverty. Agricultural practices that meet the demands of society, improve farming systems and the living conditions of the farmer depend on adapted public policies. They also depend on the suitability of the technologies to different contexts (Vignola et al., 2015; Altieri; Nicholls, 2017). Each community has requirements regarding the supply and qualification of labor or investment capacity. If it is not possible to meet them, it will not be viable to disseminate the innovations (Halbrendt et al., 2014). The alternatives need to be jointly evaluated by scientists, extensionists and farmers, so that the solutions are effectively adapted.

The true spatial dispersion of traditional systems is not yet known. The technical limits of remote sensing still hamper their adequate delimitation. Census data do not provide information on an appropriate scale, and field identification is expensive and laborious. Advances that facilitate acquisition of this information are still needed for better elaboration of public policies (Hett et al., 2012; Bermeo; Couturier; Galeana Pizaña, 2014).

Some of the demands of the poorest farmers are related to alternatives that favor the intensification of traditional systems without increasing the demand for inputs, such as use of native microorganisms, management of fires, organic residues and fallow periods (Miltner; Coomes, 2015; Junqueira et al., 2016b).

Ethnopedological studies, which have been developed so far in more than 60 developing tropical countries, have become increasingly frequent. Many rural communities use their own pedological classification systems. Their understanding can improve communication with the farmer and increase the efficiency of soil mapping (Balcázar et al., 1998; Junqueira et al., 2016b). This will allow the adoption of innovations that increase productivity, diversify sources of income and improve diet (Hernández-Hernández et al., 2011), such as crop rotation and intercropping, including agroforestry. These are techniques already used by many farmers, but further research is still needed (Rahman; Rahman; Sunderland, 2012; Junqueira et al., 2016a; MorenoCalles et al., 2016; Wood; Rhemtulla; Coomes, 2016).

Mechanization of agriculture has reduced interest in the development of animal-drawn implements. It is necessary to keep their improvements and investigate their effects on soils and crops (Bertol et al., 2000). Finally, it is necessary to reconcile the productive intensification with the limits of each productive logic and of each ecosystem. The way opened by agroecology has shown the urgent need to translate traditional agricultural practices into new sustainable practices, adapted to diverse contexts, particularly in developing tropical countries.

\section{REFERENCES}

Altieri, M. A.; FUnes-MOnZOTE, F. R.; PETERSEN, P. Agroecologically efficient agricultural systems for smallholder farmers: Contributions to food sovereignty. Agronomy for Sustainable Development, 32(1):1-13, 2012.

ALTIERI, M. A.; NICHOLLS, C. I. The adaptation and mitigation potential of traditional agriculture in a changing climate. Climatic Change, 140(1):33-45, 2017.

ALTIERI, M. A.; TOLEDO, V. M. The agroecological revolution in Latin America: Rescuing nature, ensuring food sovereignty and empowering peasants. Journal of Peasant Studies, 38(3):587-612, 2011.

ASSAINAR, S. K. et al. Response of wheat to a multiple species microbial inoculant compared to fertilizer application. Frontiers in Plant Science, 9:1601, 2018.

BALCÁZAR, R. C. et al. Clasificacion de tierras campesina para la generación y transferencia de tecnología agrícola entre pequeños productores: Caso del maíz en la región central de Veracruz. Terra Latinoamericana, 16(1):1-10, 1998.

BAUTISTA, J. A.; SMIT, M. A. Sustentabilidad y agricultura en la "región del mezcal" de Oaxaca. Revista Mexicana de Ciencias Agrícolas, 3(1):5-20, 2012.

BAZIN, F. A agricultura familiar: Comparaçao internacional: Do mito à realidade. Campinas: UNICAMP, 1998. 348p.

BÉLIVEAU, A. et al. Early effects of slash-and-burn cultivation on soil physicochemical properties of small-scale farms in the Tapajós region, Brazilian Amazon. The Journal of Agricultural Science, 153(2):205-221, 2015.

BELLETTI, M. The emerging role of the peasant economy at the end of the industrial age: Insights from Albania. Procedia Economics and Finance, 33:78-89, 2015.

BERMEO, A.; COUTURIER, S.; GALEANA PIZAÑA, M. Conservation of traditional smallholder cultivation systems in indigenous territories: Mapping land availability for milpa cultivation in the Huasteca Poblana, Mexico. Applied Geography, 53:299-310, 2014.

BERTOL, I. et al. Propriedades físicas e químicas e produtividade de milho afetadas pelo manejo do solo com tração animal, numa terra bruna estruturada. Ciência Rural, 30(6):971976, 2000. 
BROWN, O. M.; GIL, R. E. R. Tecnologías limpias aplicadas a la agricultura. Interciencia, 28(5):252-258, 2003.

CARMONA, A. et al. Linking farming systems to landscape change: An empirical and spatially explicit study in southern Chile. Agriculture, Ecosystems and Environment, 139(12):40-50, 2010.

DAROLT, M. R. et al. Alternative food networks and new producer-consumer relations in France and in Brazil. Ambiente \& Sociedade, 19(2):1-22, 2016.

EMPERAIRE, L.; ELOY, L. Amerindian agriculture in an urbanising Amazonia (Rio Negro, Brazil). Bulletin of Latin American Research, 34(1):70-84, 2015.

ENGLANDER, A. C.; DOUDS, D. D.; MALLORY, E. B. On-farm produced microbial soil inoculant effects on bread wheat (Triticum aestivum) production. Biological Agriculture and Horticulture, 32(2):85-97, 2016.

FELIPIM, A. P.; QUEDA, O. O sistema agrícola Guarani Mbyá e seus cultivares de milho: Um estudo de caso. Interciencia, 30(3):143-150, 2005.

FERNANDES, R. S. de; SILVA, A. M. da; FALCÃO, R. P. The pluriativity as a factor of generation of income for family farming of Córrego Primavera, Rio Bananal, Espírito Santo, Brazil. Extensão Rural, 25(2):52-72, 2018.

FILIPE, F. S. de et al. Legumes as green manure for common bean cultivated in two growing seasons at southeast Brazil. African Journal of Agricultural Research, 11(49):49534958, 2016.

FITZ-KOCH, S. et al. Entrepreneurship in the Agricultural Sector: A literature review and future research opportunities. Entrepreneurship Theory and Practice, 42(1):129-166, 2018.

GAONA, A. F.; LEÓN, A. C.; VALVERDE, B. R. Cambio tecnológico y tecnología comunitaria en El Valle Morelia-Querendaro, Michoacán, Mexico. Revista Mexicana de Ciencias Agrícolas, 3(7):1305-1320, 2012.

GARCÍA-FLORES, J. C. et al. Estrategia de vida en el medio rural del altiplano central mexicano: El huerto familiar. Agricultura, Sociedad y Desarrollo, 13(4):621-641, 2016.

GONZÁLEZ-PÉREZ, J. A. et al. The effect of fire on soil organic matter - A review. Environment International, 30(6):855870, 2004.

HALBRENDT, J. et al. Implications of conservation agriculture for men's and women's workloads among marginalized farmers in the central middle hills of Nepal. Mountain Research and Development, 34(3):214-222, 2014.
HANSEN, T. S.; MERTZ, O. Extinction or adaptation? Three decades of change in shifting cultivation in Sarawak, Malaysia. Land Degradation \& Development, 17(2):135148, 2006.

HART, M. M. et al. Fungal inoculants in the field: Is the reward greater than the risk? Functional Ecology, 32(1):126-135, 2018.

HERNÁNDEZ-HERNÁNDEZ, R. et al. La integración del conocimiento local y científico en el manejo sostenible de suelos en agroecosistemas de sabanas. Interciencia, 36(2):104-112, 2011.

HERRICK, J. E. et al. Rangeland soil erosion and soil quality: Role of soil resistance, resilience, and disturbance regime. In: RATTA, R.; LAL, R. Soil Quality and Soil Erosion. Columbus: CRC Press, 1998. p.209-233.

HETT, C. et al. A landscape mosaics approach for characterizing swidden systems from a REDD+ perspective. Applied Geography, 32(2):608-618, 2012.

INBAR, A. et al. Forest fire effects on soil chemical and physicochemical properties, infiltration, runoff, and erosion in a semiarid Mediterranean region. Geoderma, 221-222:131-138, 2014.

JIMÉNEZ-PINILLA, P. et al. Advances in the knowledge of how heating can affect aggregate stability in Mediterranean soils: A XDR and SEM-EDX approach. Catena, 147:315324, 2016.

JUNQUEIRA, A. B. et al. Variation in soil fertility influences cycle dynamics and crop diversity in shifting cultivation systems. Agriculture, Ecosystems \& Environment, 215:122-132, 2016a.

JUNQUEIRA, A. B. et al. The role of Amazonian anthropogenic soils in shifting cultivation: Learning from farmers' rationales. Ecology and Society, 21(1):12, $2016 \mathrm{~b}$.

KLEINMAN, P.; PIMENTEL, D.; BRYANTC, R. B. The ecological sustainability of slash-and-burn agriculture. Agriculture, Ecosystems \& Environment, 52(2-3):235-249, 1995.

KOVACIC, Z.; VITERI SALAZAR, O. The lose - lose predicament of deforestation through subsistence farming: Unpacking agricultural expansion in the Ecuadorian Amazon. Journal of Rural Studies, 51:105-114, 2017.

LESTRELIN, G. et al. Challenging established narratives on soil erosion and shifting cultivation in Laos. Natural Resources Forum, 36(2):63-75, 2012.

LI, P. et al. A review of swidden agriculture in southeast Asia. Remote Sensing, 6(2):1654-1683, 2014. 
LIMA, S. S. de et al. Atributos químicos e estoques de carbono e nitrogênio em argissolo vermelho-amarelo sob sistemas agroflorestais e agricultura de corte e queima no norte do Piauí. Revista Árvore, 35(1):51-60, 2011.

MARTÍNEZ-CASTILLO, R. Agricultura tradicional campesina: Características ecológicas. Revista Tecnología en Marcha, 21(3):3-13, 2008.

MARTÍNEZ-CASTILLO, R. Sistemas de producción agrícola sostenible. Revista Tecnología en Marcha, 22(2):23-39, 2009.

MATAIX-SOLERA, J. et al. Fire effects on soil aggregation: A review. Earth-Science Reviews, 109(1-2):44-60, 2011.

MCNICOL, I. M.; RYAN, C. M.; WILLIAMS, M. How resilient are African woodlands to disturbance from shifting cultivation? Ecological Applications, 25(8):2320-2336, 2015.

MEENA, B. L. et al. Legume green manuring: An option for soil sustainability. In: MEENA, R. S. et al. (Eds). Legumes for Soil Health and Sustainable Management. Singapore: Springer Singapore, 2018. p.387-408.

MERTZ, O. et al. Changes in shifting cultivation systems on small Pacific islands. The Geographical Journal, 178(2):175-187, 2012.

MILTNER, B. C.; COOMES, O. T. Indigenous innovation incorporates biochar into swidden-fallow agroforestry systems in Amazonian Peru. Agroforestry Systems, 89(3):409-420, 2015.

MORALES-BARQUERO, L. et al. Identification and quantification of drivers of forest degradation in tropical dry forests: A case study in Western Mexico. Land Use Policy, 49:296309, 2015.

MORENO-CALLES, A. I. et al. Ethnoagroforestry: Integration of biocultural diversity for food sovereignty in Mexico. Journal of Ethnobiology and Ethnomedicine, 12(1):54, 2016.

MUKUL, S. A.; HERBOHN, J. The impacts of shifting cultivation on secondary forests dynamics in tropics: A synthesis of the key findings and spatio temporal distribution of research. Environmental Science \& Policy, 55:167-177, 2016.

MÜLLER, R. et al. Policy options to reduce deforestation based on a systematic analysis of drivers and agents in lowland Bolivia. Land Use Policy, 30(1):895-907, 2013.

NYSSEN, J. et al. Soils and land use in the Tigray highlands (Northern Ethiopia). Land Degradation \& Development, 19(3):257-274, 2008.
O'CALLAGHAN, M. Microbial inoculation of seed for improved crop performance: Issues and opportunities. Applied Microbiology and Biotechnology, 100(13):5729-5746, 2016.

PÉREZ-GARCÍA, O.; CASTILLO, R. F. del. The decline of the itinerant milpa and the maintenance of traditional agrobiodiversity: Crops and weeds coexistence in a tropical cloud forest area in Oaxaca, Mexico. Agriculture, Ecosystems \& Environment, 228:30-37, 2016.

PRACH, K. et al. Possibilities and limitations of passive restoration of heavily disturbed sites. Landscape Research, 6397:1-7, 2019.

PRETTY, J.; BHARUCHA, Z. P. Sustainable intensification in agricultural systems. Annals of Botany, 114(8):1571-1596, 2014.

PROKOP, P.; PORĘBA, G. J. Soil erosion associated with an upland farming system under population pressure in northeast India. Land Degradation \& Development, 23(4):310-321, 2012.

RACZKOWSKI, C. W. et al. Soil physical properties of agricultural systems in a large-scale study. Soil and Tillage Research, 119:50-59, 2012.

RAHMAN, S. A.; RAHMAN, M. F.; SUNDERLAND, T. Causes and consequences of shifting cultivation and its alternative in the hill tracts of eastern Bangladesh. Agroforestry Systems, 84(2):141-155, 2012.

RIGG, J.; SALAMANCA, A.; THOMPSON, E. C. The puzzle of East and Southeast Asia's persistent smallholder. Journal of Rural Studies, 43:118-133, 2016.

RIVAS, Á.; QUINTERO, H. Reappraising the multiple functions of traditional agriculture within the context of building rural development investigative skills. Agronomía Colombiana, 32(1):130-137, 2014.

SABOURIN, E. Camponeses do Brasil: Entre a troca mercantil e a reciprocidade. Rio de Janeiro: Garamond, 2009. 328p.

SÁNCHEZ, P. A. Nitrogen in shifting cultivation systems of Latin America. Plant and Soil, 67(1-3):91-103, 1982.

SEITZ, S. et al. Conservation tillage and organic farming reduce soil erosion. Agronomy for Sustainable Development, 39(1):4, 2019.

SOPER, R. Local is not fair: Indigenous peasant farmer preference for export markets. Agriculture and Human Values, 33(3):537-548, 2016. 
SOUZA, B. D. J. et al. Productores agroecológicos y su percepción sobre el uso del abono verde en el Sudeste de Minas Gerais, Brasil. Idesia (Arica), 36(3):15-25, 2018.

STAVI, I.; BEL, G.; ZAADY, E. Soil functions and ecosystem services in conventional, conservation, and integrated agricultural systems. A review. Agronomy for Sustainable Development, 36(2):32, 2016.

TAVEIRA, L. R. S. et al. Mapping land use capability in tropical conditions adapting criteria to different levels of agricultural management. Ciência e Agrotecnologia, 42(6):631-642, 2018.

THOMAZ, E. L. Slash-and-burn agriculture: Establishing scenarios of runoff and soil loss for a five-year cycle. Agriculture, Ecosystems \& Environment, 168:1-6, 2013.

THOMAZ, E. L. Realistic soil-heating gradient temperature linearly changes most of the soil chemical properties. Soil Science and Plant Nutrition, 63(1):84-91, 2017.

THOMAZ, E. L.; ANTONELI, V.; DÖERR, S. H. Effects of fire on the physicochemical properties of soil in a slash-and-burn agriculture. Catena, 122:209-215, 2014.

TINKER, P. B.; INGRAM, J. S. I.; STRUWE, S. Effects of slashand-burn agriculture and deforestation on climate change. Agriculture, Ecosystems \& Environment, 58(1):13-22, 1996.

TOGNI, P. H. B. et al. Biodiversity provides whitefly biological control based on farm management. Journal of Pest Science, 92(2):393-403, 2019.

TREMBLAY, S. et al. Agroforestry systems as a profitable alternative to slash and burn practices in small-scale agriculture of the Brazilian Amazon. Agroforestry Systems, 89(2):193-204, 2015.

URCOLA, M. Estrategias socio-productivas y agricultura familiar: Las nuevas tecnologías y sus implicancias en las relaciones familiares y productivas en una localidad del sur santafesino. Mundo Agrario, 13(26): 1-30, 2013.

VALLEJO, M. et al. Agroforestry systems in the highlands of the Tehuacán Valley, Mexico: Indigenous cultures and biodiversity conservation. Agroforestry Systems, 88(1):125-140, 2014.

VANACKER, V. et al. Land use impacts on soil erosion and rejuvenation in Southern Brazil. Catena, 178:256-266, 2019.

VIGNOLA, R. et al. Ecosystem-based adaptation for smallholder farmers: Definitions, opportunities and constraints. Agriculture, Ecosystems \& Environment, 211:126-132, 2015.

VLIET, J. A. VAN. et al. De-mystifying family farming: Features, diversity and trends across the globe. Global Food Security, 5:11-18, 2015.

VLIET, N. VAN. et al. Trends, drivers and impacts of changes in swidden cultivation in tropical forest-agriculture frontiers: A global assessment. Global Environmental Change, 22(2):418-429, 2012.

VOSTI, S. A.; WITCOVER, J. Slash-and-burn agriculture Household perspectives. Agriculture, Ecosystems \& Environment, 58(1):23-38, 1996.

WAGNER, A.; YAP, D. L. T.; YAP, H. T. Drivers and consequences of land use patterns in a developing country rural community. Agriculture, Ecosystems \& Environment, 214:78-85, 2015.

WOOD, S. L. R.; RHEMTULLA, J. M.; COOMES, O. T. Intensification of tropical fallow-based agriculture: Trading-off ecosystem services for economic gain in shifting cultivation landscapes? Agriculture, Ecosystems \& Environment, 215:47-56, 2016.

$\mathrm{XIE}, \mathrm{Z}$. et al. Substitution of fertilizer-N by green manure improves the sustainability of yield in double-rice cropping system in south China. Field Crops Research, 188:142149, 2016.

YENGOH, G. T.; BROGAARD, S. Explaining low yields and low food production in Cameroon: A farmers' perspective. GeoJournal, 79(3):279-295, 2014.

ZANELLA, M. A.; MILHORANCE, C. Cerrado meets savannah, family farmers meet peasants: The political economy of Brazil's agricultural cooperation with Mozambique. Food Policy, 58:70-81, 2016. 